\title{
Meningkatkan Kemampuan Dasar Kognitif Melalui Permainan "Rainbowling" Pada Anak Kelompok B-1 Tk Islam Al Falah Kecamatan Pesantren Kota Kediri
}

\author{
Suwarti \\ Tk Islam Al Falah Kecamatan Pesantren \\ Kota Kediri \\ drasuwartimpd@gmail.com
}

\begin{abstract}
Abstrak
Berdasarkan pengamatan terhadap kegiatan pengembangan anak kelompok B-1 TK Islam Al-Falah Kecamatan Pesantren Kota Kediri, ditemukan rendahnya informasi anak tentang cabang olahraga terutama olahraga bowling, serta kurang antusias dan semangat dalam kegiatan belajar mengajar yang kemungkinan disebabkan cara penyampaian pendidik yang kurang menarik dan cenderung pasif untuk anak-anak. Sesuai permasalahan tersebut, diperlukan strategi pembelajaran yang menarik, efektif, dan menyenangkan sehingga dapat mengembangkan kemampuan dasar kognitif anak.Melalui Permainan Rainbowling diharapkan dapat mengembangkan kemampuan dasar kognitif anak dengan mudah dan anak tidak merasa bosan. Bentuk tindakan yang akan dilakukan yaitu dengan melalui Permainan "Rainbowling" dapat mengembangkan kemampuan dasar kognitif pada anak didik karena melalui permainan ini anak tidak merasa bosan dan memberi kesempatan anak untuk aktif. Berdasarkan latar belakang yang terjadi, penulisan ini dilakukan dengan tujuan untuk mengetahui bahwa melalui Permainan "Rainbowling" dapat meningkatkan kemampuan dasar kognitif pada anak kelompok B-1 TK Islam Al-Falah Kecamatan Pesantren Kota Kediri. Subyek dalam penelitian ini adalah siswa kelompok B-1 TK Islam AlFalah Kecamatan Pesantren tahun pelajaran 2015-2016 yang beralamatkan di J1. Brigjend.Pol. Imam Bachri No.123 Kota Kediri, dengan jumlah anak didik 21 anak terdiri dari 7 anak perempuan dan 14 anak laki-laki. Anak didik ini menjadi sasaran dan sekaligus sebagai sumber data penelitian. Berdasarkan data di atas, ketuntasan kemampuan dasar kognitif anak didik mengalami peningkatan. Hal tersebut nampak dari prosentase ketuntasan kemampuan dasar kognitif anak didik pada pratindakan dan pada siklus I yang hanya mencapai 66,7\%. Kemudian kemampuan dasar kognitif anak didik mengalami peningkatan pada siklus II yaitu $85,7 \%$. Berdasarkan hasil penelitian dan pembahasan yang dilakukan dapat disimpulkan bahwa melalui Permainan Rainbowling dapat mengembangkan kemampuan dasar kognitif anak didik kelompok B-1 TK Islam Al-Falah Kecamatan Pesantren Kota Kediri Tahun Ajaran 2015/2016. Selain itu minat anak untuk memahami konsep berhitung semakin meningkat setelah dilakukan dengan permainan Permainan Rainbowling.
\end{abstract}

Kata Kunci: Kemampuan Kognitif, Permainan Rainbowling, Anak Kelompok B 


\section{PENDAHULUAN}

Kemampuan dasar kognitif (Logical Mathematical) merupakan salah satu aspek penting dalam usia taman kanak-kanak. Usia taman kanak-kanak merupakan usia anak mengenal, memahami, dan mengeksplorasi sesuatu yang baru. Dalam mengenal, memahami, dan mengeksplorasi sesuatu anak pasti menggunakan kognitif dalam mengolah informasi dan pengetahuan yang didapat, sehingga anak usia taman kanak-kanak cenderung aktif dalam mengeksplorasi. Dengan kemampuan dasar kognitif dimaksudkan agar anak dapat mengembangkan daya pikirnya, dapat memahami bilangan sederhana, serta mampu memahami konsep dasar matematika sederhana.Logical Mathematical berkaitan dengan hal yang sangat luas dalam kehidupan sehari-hari antara lain rasio/logika atau pengembangan daya 119iker, berhitung, ilmu ukur, memahami konsep-konsep dasar matematika sederhana, dan lain-lain.

Berdasarkan pengamatan terhadap kegiatan pengembangan anak kelompok B1 TK Islam Al-Falah Kecamatan Pesantren Kota Kediri, ditemukan rendahnya informasi anak tentang cabang olahraga terutama olahraga bowling, serta kurang antusias dan semangat dalam kegiatan belajar mengajar yang kemungkinan disebabkan cara penyampaian pendidik yang kurang menarik dan cenderung pasif untuk anak-anak. Sesuai permasalahan tersebut, diperlukan strategi pembelajaran yang menarik, efektif, dan menyenangkan sehingga dapat mengembangkan kemampuan dasar kognitif anak.Melalui Permainan Rainbowling diharapkan dapat mengembangkan kemampuan dasar kognitif anak dengan mudah dan anak tidak merasa bosan.

Bentuk tindakan yang akan dilakukan yaitu dengan melalui Permainan "Rainbowling" dapat mengembangkan kemampuan dasar kognitif pada anak didik karena melalui permainan ini anak tidak merasa bosan dan memberi kesempatan anak untuk aktif. Berdasarkan latar belakang yang terjadi, penulisan ini dilakukan dengan tujuan untuk mengetahui bahwa melalui Permainan "Rainbowling" dapat meningkatkan kemampuan dasar kognitif pada anak kelompok B-1 TK Islam Al-Falah Kecamatan Pesantren Kota Kediri.

\section{KAJIAN PUSTAKA}

Karakteristik Anak Taman Kanakkanak pada umumnya adalah anak yang selalu bergerak, mempunyai rasa ingin tahu yang kuat, senang bereksperimen dan menguji, mampu mengekspresikan diri secara kreatif, mempunyai imajinasi, senang berbicara.

Menurut Clark, karakteristik anak prasekolah adalah mempunyai pemikiran yang sangat logis, selalu ingin bersenangsenang dan bermain, kreatif, dan mampu menceritakan apa yang sedang mereka lakukan. Yang dimaksud anak prasekolah adalah mereka yang berusia 3-6 tahun (Bichler dan Snowman 1993, dalam Patmonodewo, 2000).

Proses pembelajaran di Taman Kanak-kanak harus mengacu pada karakteristik anak sehingga tujuan dari pembelajaran dapat tercapai sesuai dengan yang diharapkan. Dengan mengetahui/memahami karakteristik anak akan membantu pendidik menemukan/ menciptakan model pembelajaran yang sesuai dengan menarik minat anak. Oleh karena itu model pembelajaran yang sesuai dan diminati anak harus dirancang secara seksama sehingga dalam proses belajar mengajar dapat memberikan kesempatan belajar yang menyenangkan bagi anak.

Menghubungkan kemampuan yang diharapkan dengan pekerjaan atau kehidupan sehari-hari menjadikan anak didik semakin akrab/dekat dengan lingkungannya sehingga mampu menguasai suatu konsep yang abstrak melalui pengalaman belajar yang konkrit. Bermain merupakan satu dari sekian macam karakteristik anak taman kanak-kanak yang 
sangat efektif untuk mengembangkan atau mendukung semua aspek perkembangan anak, baik aspek bidang pengembangan pembiasaan yang meliputi moral dan nilainilai agama, sosial emosional, dan kemandirian maupun aspek bidang pengembangan kemampuan dasar yang meliputi kemampuan kognitif (logical mathematical), berbahasa, seni, maupun fisik motorik. Dengan bermain akan memungkinkan anak meneliti lingkungannya, mempelajari segala sesuatu dan memecahkan masalah yang dihadapinya.

Sedangkan menurut Hetherington dan Parke (1990, dalam Moeslichtoen, 2005) menegmukakan bahwa fungsi bermain dan interaksi dalam permainan mempunyai peran penting bagi perkembangan kognitif (logical mathematical), dan sosial anak.

Selain itu motivasi merupakan salah satu faktor yang dapat meningkatkan kualitas pembelajaran, karena peserta didik akan belajar dengan sungguh-sungguh apabila memiliki motivasi belajar yang tinggi. Oleh karena itu untuk meningkatkan kualitas pembelajaran guru harus mampu membangkitkan motivasi belajar anak sehingga dapat mencapai tujuan pembelajaran (Mulyasa, 2006). Karena itu pendidik harus memberikan kesempatan kepada anak untuk mengekspresikan diri secara kreatif karena hal ini akan menimbulkan gairah untuk belajar. Banyak sekali bentuk model pembelajaran yang berkembang saat ini dan masing-masing memilki karakteristik yang berbeda.Pendidik dapat memilih model pembelajaran yang disesuaikan dengan karakteristik yang berbeda.Pendidik dapat memilih model pembelajaran yang disesuaikan dengan karakter anak didiknya untuk mencapai tujuan yang diharapkan.

\section{Logical Mathematical}

Menurut Piaget seorang ahli dalam bidang biologi dan kemudian tertarik dengan ilmu pengetahuan, proses belajar dan cara berpikir mengemukakan bahwa logical mathematical merupakan salah satu cara bagaimana anak mengetahui sesuatu. Kategori ini meliputi pengertian tentang angka, klasifikasi, waktu, dan ruang. Tipe pengetahuan ini menunjukkan adanya proses mental yang dikaitkan dengan hadirnya benda secara fisik. Misalnya seorang yang melihat 2 batang pensil sekaligus dan anak dapat mengatakan "dua pensil".Hal ini dapat terjadi karena anak menggunakan suatu konstruksi mental. Berarti anak dapat memahami pemikirannya terhadap dua buah pensil dengan cara "one to one correspondence" (Patmonodewo, 2000).

Untuk dapat membantu anak dalam mengembangkan kemampuan logical mathematical, Freeman (1996, dalam Patmonodewo, 2000) mengungkapkan cara merangsang logical mathematical anak yaitu bermain dengan air untuk memperoleh ide tentang mengisi gelas, mengapung, tenggelam, dan lain-lain. Ketika mengisi gelas dengan air akan membangkitkan ide-ide anak tentang jumlah (banyaknya benda), bermain dengan adonan tepung, meremas adonan, dan membagi-bagi adonan.

\section{Permaian Rainbowling}

Permainan Rainbowling merupakan permainan yang terinspirasi dari olah raga/permainan bowling.Rainbowling berasal dari kata rainbow yang berarti pelangi dan bowling, jadi rainbowling merupakan bowling pelangi.Bowling adalah jenis olahraga atau permainan yang dimainkan dengan menggelindingkan bola khusus menggunakan satu tangan. Bola bowling akan digelindingkan ke pin yang berjumlah sepuluh buah yang telah disusun menjadi bentuk segitiga jika dilihat dari atas (Wikipedia, 2015).

Permainan Rainbowling tercipta dengan bahan sederhana, mudah didapat, dan ramah lingkungan karena memanfaatkan sampah plastik. Permainan bowling yang menggunakan pin sebanyak 10 buah, sama halnya dengan Permainan Rainbowling menggunakan pin sebanyak 
10 buah yang terbuat dari botol bekas air mineral, sedangkan bola terbuat dari kertas bekas dan tas plastik bekas yang disatukan dibentuk seperti bola. Cara memainkan Permainan Rainbowling yaitu dengan menggelindingkan bola (kumpulan kertas dan tas plastik bekas) ke arah pin (botol bekas air mineral yang dibungkus kertas lipat berwarna warni). Permaianan Rainbowling dapat dimainkan oleh anak berusia 5-6 tahun.

1. Alat dan Bahan Pembuatan

Permainan Rainbowling

a. Botol bekas minuman susu sapi murni

b. Kertas lipat ukuran $16 \times 16 \mathrm{~cm}$

c. Kertas bertuliskan angka 1-10

d. Gunting

e. Isolasi

f. Tas plastik bekas

g. Kertas

2. Mekanisme Penggunaan Permainan Rainbowling

Penggunaan Permainan Rainbowlingsama halnya dengan permainan bowling, botol-botol bekas yang sudah diisi kertas lipat berwarna dan ditempel angka ditata berdiri berpola segitiga bila dilihat dari atas, lalu bola digelindingkan dan ditujukan pada pin/botol-botol bekas. Setiap anak berkesempatan/berpeluang untuk 3 kali menggelindingkan bola jika gelinding pertama dan kedua gagal. Jarak antara anak dengan botol pin terdepan sekitar 3 meter.

Hubungan Permainan Rainbowling
dengan Perkembangan Kognitif Anak
Penggunaan Rainbowling sama halnya dengan permainan bowling yang sesungguhnya, bola digelindingkan dan ditujukan pada pin/botol-botol bekas. Sambil menata botol, pendidik bisa melakukan tanya jawab dengan anak tentang warna dan jumlah botol. Seperti, "Berapa jumlah botol berwarna merah, warna kuning, dan warna biru?" setelah anak menjawab pendidik bisa menanyakan "Jika ketiganya dijumlahkan maka berapa jumlahnya?" Dari tanya jawab inilah anak diajak untuk berpikir dan memahami konsep penjumlahan. Setelah anak menggelindingkan bola ke arah pin dan ada beberapa pin yang jatuh oleh bola, pendidik bisa melakukan tanya jawab, "Berapa jumlah botol yang berdiri? Setelah dilempar bola, ada berapa botol yang jatuh? Dan berapa sisa botol yang berdiri sekarang?" dari tanya jawab inilah anak diajak untuk berpikir tentang konsep pengurangan.

Dari permainan ini anak dapat memahami konsep berhitung sederhana dan menunjang perkembangan kepekaan panca indera dengan menyebutkan dan pengenalan tentang warna, selain itu dengan melemparkan bola ke arah botol dapat mengembangkan kemampuan fisik motorik kasar anak. Seperti yang dijelaskan pada tabel berikut ini:

Tabel 2.1

Aspek Perkembangan Anak yang Dapat Dikembangkan melalui Permainan Rainbowling berdasarkan "Kompetensi Inti dan Kompetensi Dasar serta Indikator Pencapaian Perkembangan Anak Kelompok B”

\begin{tabular}{|c|l|l|l|}
\hline No & $\begin{array}{c}\text { Aspek } \\
\text { Perkembang } \\
\text { an }\end{array}$ & $\begin{array}{c}\text { Kompetensi } \\
\text { dasar }\end{array}$ & \multicolumn{1}{|c|}{ Indikator } \\
\hline 1 & $\begin{array}{l}\text { Nilai Agama } \\
\text { dan Moral }\end{array}$ & $\begin{array}{l}1.2 \\
\text { Menghargai } \\
\text { diri sendiri, } \\
\text { orang lain, dan } \\
\text { lingkungan } \\
\text { sekitar. }\end{array}$ & $\begin{array}{l}\text { Menghargai } \\
\text { diri sendiri, } \\
\text { orang lain, dan } \\
\text { lingkungan } \\
\text { sekitar. }\end{array}$ \\
\hline 2 & $\begin{array}{l}\text { Sosial } \\
\text { Emosional }\end{array}$ & $\begin{array}{l}\text { 2.7 Memiliki } \\
\text { perilaku yang } \\
\text { mencerminkan } \\
\text { sikap sabar } \\
\text { (mau } \\
\text { menunggu } \\
\text { giliran, mau } \\
\text { mendengar } \\
\text { ketika orang } \\
\text { lain berbicara) } \\
\text { untuk melatih } \\
\text { kedisiplinan. }\end{array}$ & $\begin{array}{l}\text { Merilaku yang } \\
\text { mencerminkan } \\
\text { sikap sabar } \\
\text { (mau } \\
\text { menunggu } \\
\text { giliran, mau } \\
\text { mendengar } \\
\text { ketika orang } \\
\text { lain berbicara) } \\
\text { untuk melatih } \\
\text { kedisiplinan. }\end{array}$ \\
\hline
\end{tabular}




\begin{tabular}{|c|c|c|c|}
\hline \multirow[t]{2}{*}{3} & Kognitif & $\begin{array}{l}\text { 3.6 Mengenal } \\
\text { benda-benda } \\
\text { di sekitarnya } \\
\text { (nama, warna, } \\
\text { bentuk, } \\
\text { ukuran, pola, } \\
\text { sifat, suara, } \\
\text { tekstur, dan } \\
\text { ciri lainnya) }\end{array}$ & $\begin{array}{l}\text { Melakukan } \\
\text { kegiatan yang } \\
\text { menunjukkan } \\
\text { anak mampu } \\
\text { mengenal } \\
\text { benda dengan } \\
\text { mengelompok } \\
\text { kan berbagai } \\
\text { benda di } \\
\text { lingkungannya } \\
\text { berdasarkan } \\
\text { ukuran, pola, } \\
\text { fungsi, sifat, } \\
\text { dan ciri yang } \\
\text { lainnya. }\end{array}$ \\
\hline & & $\begin{array}{l}\text { 4.6 } \\
\text { Menyampaika } \\
\mathrm{n} \text { tentang apa } \\
\text { dan bagaiman } \\
\text { benda-benda } \\
\text { di sekitar yang } \\
\text { dikenalnya } \\
\text { (nama, warna, } \\
\text { bentuk, } \\
\text { ukuran, pola, } \\
\text { sifat, tekstur, } \\
\text { fungsi, dan } \\
\text { ciri lainnya) } \\
\text { melalui } \\
\text { berbagai hasil } \\
\text { karya. }\end{array}$ & $\begin{array}{l}\text { Melakukan } \\
\text { kegiatan yang } \\
\text { menunjukkan } \\
\text { anak mampu } \\
\text { mengenal } \\
\text { benda } \\
\text { berdasarkan } \\
\text { lima seriasi } \\
\text { atau lebih, } \\
\text { bentuk, } \\
\text { ukuran, warna, } \\
\text { atau jumlah } \\
\text { melalui } \\
\text { kegiatan } \\
\text { mengurutkan } \\
\text { benda. }\end{array}$ \\
\hline \multirow[t]{2}{*}{4} & \multirow[t]{2}{*}{ Bahasa } & $\begin{array}{l}3.10 \\
\text { Memahami } \\
\text { bahasa reseptif } \\
\text { (menyimak } \\
\text { dan membaca) }\end{array}$ & $\begin{array}{l}\text { Melakukan } \\
\text { proses kerja } \\
\text { sesuai dengan } \\
\text { prosedurnya. }\end{array}$ \\
\hline & & $\begin{array}{l}4.10 \\
\text { Menunjukkan } \\
\text { kemampuan } \\
\text { berbahasa } \\
\text { reseptif } \\
\text { (menyimak } \\
\text { dan membaca) }\end{array}$ & $\begin{array}{l}\text { Melaksanakan } \\
\text { perintah yang } \\
\text { lebih } \\
\text { kompleks } \\
\text { sesuai dengan } \\
\text { aturan yang } \\
\text { disampaikan. }\end{array}$ \\
\hline \multirow[t]{2}{*}{5} & \multirow[t]{2}{*}{$\begin{array}{l}\text { Fisik } \\
\text { motorik }\end{array}$} & $\begin{array}{l}\text { 3.3 Mengenal } \\
\text { anggota tubuh, } \\
\text { fungsi, dan } \\
\text { gerakannya } \\
\text { untuk } \\
\text { pengembanga } \\
\text { n motorik } \\
\text { kasar dan } \\
\text { motorik halus. }\end{array}$ & $\begin{array}{l}\text { Melakukan } \\
\text { kegiatan yang } \\
\text { menunjukkan } \\
\text { anak mampu } \\
\text { melakukan } \\
\text { permainan } \\
\text { fisik dengan } \\
\text { aturan. }\end{array}$ \\
\hline & & $\begin{array}{l}4.3 \\
\text { Menggunakan } \\
\text { anggota tubuh } \\
\text { untuk } \\
\text { pengembanga } \\
\text { n motorik }\end{array}$ & $\begin{array}{l}\text { Melakukan } \\
\text { kegiatan yang } \\
\text { menunjukkan } \\
\text { anak mampu } \\
\text { terampil } \\
\text { menggunakan } \\
\text { tangan kanan }\end{array}$ \\
\hline
\end{tabular}

\begin{tabular}{|c|c|c|c|}
\hline & & $\begin{array}{l}\text { kasar dan } \\
\text { halus }\end{array}$ & $\begin{array}{l}\text { dan kiri dalam } \\
\text { berbagai } \\
\text { aktifitas. }\end{array}$ \\
\hline \multirow[t]{2}{*}{6} & \multirow[t]{2}{*}{ Seni } & $\begin{array}{l}\text { 3.15 Mengenal } \\
\text { berbagai karya } \\
\text { dan aktivitas } \\
\text { seni }\end{array}$ & $\begin{array}{l}\text { Menghargai } \\
\text { penampilan } \\
\text { karya seni } \\
\text { anak lain } \\
\text { (misal dengan } \\
\text { bertepuk } \\
\text { tangan dan } \\
\text { memuji) }\end{array}$ \\
\hline & & $\begin{array}{l}4.15 \\
\text { Menunjukkan } \\
\text { karya dan } \\
\text { aktifitas seni } \\
\text { dengan } \\
\text { menggunakan } \\
\text { berbagai } \\
\text { media. }\end{array}$ & $\begin{array}{l}\text { Membuat } \\
\text { karya seni } \\
\text { sesuai } \\
\text { kreativitasnya } \\
\text { misal seni } \\
\text { musik, visual, } \\
\text { gerak dan tari } \\
\text { yang } \\
\text { dihasilkannya } \\
\text { dan dihasilkan } \\
\text { orang lain. }\end{array}$ \\
\hline
\end{tabular}

\section{METODE PENELITIAN}

Subyek dalam penelitian ini adalah siswa kelompok B-1 TK Islam Al-Falah Kecamatan Pesantren tahun pelajaran 20152016 yang beralamatkan di Jl. Brigjend.Pol. Imam Bachri No.123 Kota Kediri, dengan jumlah anak didik 21 anak terdiri dari 7 anak perempuan dan 14 anak laki-laki. Anak didik ini menjadi sasaran dan sekaligus sebagai sumber data penelitian.

Desain yang digunakan dalam penelitian ini adalah model Penelitian Tindakan Kelas karena menggambarkan bagaimana suatu pembelajaran yang diterapkan guru sekaligus peneliti mendapatkan hasil yang ingin dicapai, dengan model rancangan yang digunakan mengacu pada model Kemmis dan Taggart (dalam Sulastri 2012) dengan 2 siklus pelaksanaan. Masing-masing siklus terdiri dari 4 tahapan, yaitu penyusunan rencana tindakan, pelaksanaan tindakan, pengamatan dan perefleksian. Penelitian ini dilakukan dalam 2 siklus, masing-masing siklus terdiri dari 4 tahapan, yaitu:

1. Penyusunan Rencana Tindakan

$$
\text { Sebelum mengadakan }
$$
penelitian, peneliti menyusun rumusan masalah, tujuan penelitian, dan membuat rencana tindakan, 
termasuk di dalamnya perangkat pembelajaran.

2. Pelaksanaan Tindakan

Pada tahap ini akan dilaksanakan proses pembelajaran sebagaimana yang telah direncanakan dengan menggunakan media Permainan Rainbowling dengan metode tanya jawab, demonstrasi, dan praktik langsung.

3. Pengamatan/Observasi

Observasi dilaksanakan saat pembelajaran

berlangsung.Observasi

dilaksanakan terhadap aktivitas anak didik pada saat melaksanakan pembelajaran dengan menggunakan lembar observasi anak didik.

4. Refleksi

Refleksi dilakukan setelah tindakan, untuk mengevaluasi hasil belajar dan hasil observasi serta menganalisa hasil belajar dan hasil observasi. Jika ada kekurangan maka perbaikan akan dilakukan pada siklus berikutnya.

Penelitian yang dilakukan pada anak didik kelompok B-1 TK Islam Al-Falah Kecamatan Pesantren ini dilaksanakan dalam 2 siklus dengan langkah-langkah sebagai berikut:

\section{SIKLUS I}

a. Penyusunan Rencana Tindakan

Penyusunan rencana tindakan ini dilakukan dengan:

1) Mempersiapkan Rencana Program Pembelajaran Mingguan (RPPM)

2) Mempersiapkan Rencana Program Pembelajaran Harian (RPPH)

3) Mempersiapkan materi dengan Permainan Rainbowling

4) Mempersiapkan format penilaian kemampuan dasar kognitif

b. Pelaksanaan Tindakan

Pada penelitian siklus I peneliti menjelaskan tentang Permainan Rainbowling, memberikan contoh cara bermain Permainan Rainbowling dengan metode demonstrasi. Setiap setelah melempar bola dan mengenai sasaran, dilakukan tanya jawab tentang jumlah sasaran yang roboh dan sisa yang masih berdiri agar anak lebih paham tentang konsep dasar berhitung pengurangan, anak menata kembali sasaran (botol) yang roboh sesuai pola pin bowling yaitu berbentuk segitiga.

c. Observasi Peneliti melakukan observasi
selama kegiatan pembelajaran berlangsung.Observasi dilakukan untuk mengetahui sejauh mana perubahan kemampuan dasar kognitif anak. Hasil observasi tersebut akan mempengaruhi tindakan selanjutnya.

d. Refleksi

Refleksi merupakan tahapan untuk memproses data atau masukan yang diperoleh pada saat observasi.Tujuan dari refleksi adalah memperoleh data yang menunjukkan perubahan kemampuan dasar kognitif dan mengubah perencanaan pada siklus berikutnya untuk peningkatan kemampuan dasar kognitif anak.

\section{SIKLUS II}

a. Penyusunan Rencana Tindakan

Penyusunan rencana tindakan ini dilakukan dengan:

1) Mempersiapkan Rencana Program Pembelajaran Mingguan (RPPM)

2) Mempersiapkan Rencana Program Pembelajaran Harian (RPPH)

3) Mempersiapkan materi dengan Permainan Rainbowling

4) Mempersiapkan format penilaian kemampuan dasar kognitif

b. Pelaksanaan Tindakan

Pada penelitian siklus II, peneliti menanyakan kembali tentang Permainan Rainbowling, peneliti juga bertanya tentang jumlah sasaran yang roboh pada setiap anak untuk melatih daya ingat anak.Kemudian peneliti 
melaksanakan kegiatan pembelajaran dengan Permainan Rainbowling seperti siklus sebelumnya.

c. Observasi

Peneliti melakukan observasi selama kegiatan pembelajaran berlangsung.Observasi dilakukan untuk mengetahui sejauh mana perubahan kemampuan dasar kognitif anak pada siklus II. Hasil observasi tersebut akan mempengaruhi tindakan selanjutnya.

d. Refleksi

Refleksi pada penelitian siklus II ini terjadi perubahan kemampuan dasar kognitif yang signifikan ke arah yang positif.

Instrumen pengumpulan data yang digunakan dalam penelitian tindakan kelas ini berupa unjuk kerja anak dan observasi pada pendidik.

1. Observasi

Observasi merupakan suatu pengamatan secara sistematik terhadap perilaku yang nampak pada objek.Observasi dilakukan pada pendidik saat kegiatan berlangsung. Data yang diperoleh dari instrumen observasi akan menjadi landasan refleksi pada siklus I dan II. Instrumen observasi dalam penelitian tindakan kelas ini hanya terdiri dari lembar observasi guru/pendidik.

2. Unjuk Kerja

Lembar hasil pengamatan berikutnya adalah lembar hasil unjuk kerja anak didik.Unjuk kerja merupakan penilaian berdasarkan keaktifan anak didik dalam kegiatan pembelajaran. Sedangkan ketentuan ketuntasan perkembangan anak adalah apabila anak didik telah mencapai $75 \%$ perkembangan kemampuan dasar kognitif daripada kemampuan sebelumnya.

Teknik analisis data berisi mengenai proses, hasil, dan hambatan yang dijumpai selama proses pembelajaran berlangsung, yaitu cara yang dipergunakan untuk mengolah data dan hasil penelitian yang diperoleh, sehingga dapat diambil kesimpulannya. Prosedur analisis data dalam penelitian ini adalah:

1. Menghitung distribusi frekuensi tanda bintang $(\star)$ ) dengan menggunakan rumus sebagai berikut:

$$
\mathbf{P}=\frac{\bar{F}}{F} \times 100 \%
$$

Keterangan :

$\mathrm{P}=$ Hasil prosentase anak yang mendapat bintang $(\star)$ tertentu

$\mathrm{F}=$ Jumlah anak yang mendapatkan bintang tertentu

$\mathrm{N}=$ Jumlah keseluruhan anak

2. Membandingkan ketuntasan belajar anak didik dalam hal kemampuan dasar kognitifnya, mulai dari pra tindakan, siklus I dan II.

Keseluruhan rencana pelaksanaan penelitian tindakan kelas ini dilaksanakan selama kurang lebih 2 minggu.Rencana jadwal penelitian ini dibuat agar penelitian tindakan kelas ini dapat terprogram dengan baik.

\section{HASIL DAN PEMBAHASAN}

Model rancangan yang digunakan dalam penelitian tindakan kelas ini mengacu pada model Kemmis dan Taggart (dalam Sulastri, 2012) dengan 2 siklus pelaksanaan.Masing-masing siklus terdiri dari 4 tahapan, yaitu penyusunan rencana tindakan, pelaksanaan tindakan, pengamatan (observasi), dan refleksi. Adapun deskripsi setiap siklus adalah sebagai berikut:

1. Pelaksanaan Tindakan pada Siklus I a. Perencanaan

Peneliti melakukan halhal sebagai berikut:

1) Mempersiapkan Rencana Program Pembelajaran Mingguan (RPPM) 
2) Mempersiapkan Rencana Program Pembelajaran Harian (RPPH)

3) Mempersiapkan materi dengan Permainan Rainbowling

4) Mempersiapkan format penilaian kemampuan dasar kognitif

b. Pelaksanaan

Pada pelaksanaan siklus I, 21 anak didik kelompok B-1 TK Islam Al-Falah hadir.Pada tahap ini peneliti menerapkan kegiatan sesuai dengan persiapan yang telah direncanakan sebelumnya yaitu mengacu pada RPPM dan RPPH yang telah disusun. Secara garis besar kegiatan yang dilakukan dalam proses pembelajaran dalam siklus I ini adalah sebagai berikut:

1) Guru menyampaikan tujuan pembelajaran

2) Guru menjelaskan bahan yang digunakan untuk membuat Permainan Rainbowling

3) Guru aktif dalam memberikan contoh bermain Permainan Rainbowling

4) Guru aktif melakukan tanya jawab seputar hasil yang didapat setelah melempar bola dalam kegiatan Permainan Rainbowling

5) Guru memotivasi anak dalam melaksanakan kegiatan bermain Permainan Rainbowling

c. Observasi

Pada tahap observasi siklus I ini, peneliti melakukan observasi sesuai dengan format yang telah dibuat. Hal ini bertujuan untuk mengetahui danmemperoleh gambaran tentang perkembangan proses pembelajaran yang terjadi. Observasi dilakukan pada anak didik kelompok B-1 dan pada peneliti/guru.Adapun hasil observasi tersebut pada siklus I sebagai berikut:

Tabel 4.1

Lembar Hasil Observasi pada Guru dalam Kegiatan Mengembangkan Kemampuan Dasar Kognitif Anak Didik melalui Permainan Rainbowling pada Siklus I

\begin{tabular}{|c|l|c|c|}
\hline No & \multicolumn{1}{|c|}{ Item observasi } & Ya & Tidak \\
\hline 1 & $\begin{array}{l}\text { Guru menyampaikan } \\
\text { tujuan pembelajaran }\end{array}$ & & $\checkmark$ \\
\hline 2 & $\begin{array}{l}\text { Guru menjelaskan } \\
\text { bahan yang digunakan } \\
\text { untuk membuat } \\
\text { Permainan } \\
\text { Rainbowling }\end{array}$ & $\checkmark$ \\
\hline 3 & $\begin{array}{l}\text { Guru aktif dalam } \\
\text { memberikan contoh } \\
\text { bermain Permainan } \\
\text { Rainbowling }\end{array}$ & $\checkmark$ & \\
\hline \multirow{2}{*}{$\begin{array}{l}\text { Guru aktif melakukan } \\
\text { tanya jawab seputar } \\
\text { hasil yang didapat } \\
\text { Setelah melempar bola } \\
\text { dalam kegiatan } \\
\text { Permainan } \\
\text { Rainbowling }\end{array}$} & $\checkmark$ & \\
\hline 5 & $\begin{array}{l}\text { Guru memotivasi anak } \\
\text { dalam melaksanakan } \\
\text { kegiatan bermain } \\
\text { Permainan } \\
\text { Rainbowling }\end{array}$ & \\
\hline
\end{tabular}

Tabel 4.2

Lembar Penilaian Perkembangan Kemampuan Dasar Kognitif Anak Didik pada Siklus I

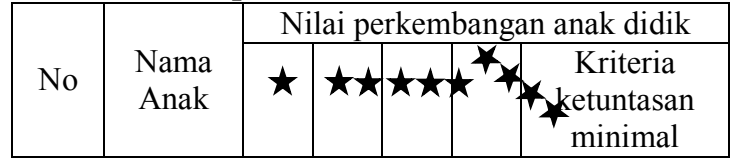




\begin{tabular}{|c|c|c|c|c|c|c|c|}
\hline & & & & & & $\begin{array}{c}\text { Tunta } \\
\mathrm{s}\end{array}$ & $\begin{array}{c}\text { Bel } \\
\text { um } \\
\text { tunt } \\
\text { as }\end{array}$ \\
\hline 1 & Amel & & & $\checkmark$ & & $\checkmark$ & \\
\hline 2 & Aar & & & $\checkmark$ & & $\checkmark$ & \\
\hline 3 & Atta & & $\checkmark$ & & & & $\checkmark$ \\
\hline 4 & Dhea & & $\checkmark$ & & & & $\checkmark$ \\
\hline 5 & Delvin & & & & $\checkmark$ & $\checkmark$ & \\
\hline 6 & Dimas & & & $\checkmark$ & & $\checkmark$ & \\
\hline 7 & Andika & & $\checkmark$ & & & & $\checkmark$ \\
\hline 8 & Vano & & & $\checkmark$ & & $\checkmark$ & \\
\hline 9 & Satria & & & $\checkmark$ & & $\checkmark$ & \\
\hline 10 & Rafi & & & $\checkmark$ & & $\checkmark$ & \\
\hline 11 & Nara & & & $\checkmark$ & & $\checkmark$ & \\
\hline 12 & Salsa & & & & $\checkmark$ & $\checkmark$ & \\
\hline 13 & Bella & & & $\checkmark$ & & $\checkmark$ & \\
\hline 14 & Vino & $\checkmark$ & & & & & $\checkmark$ \\
\hline 15 & Zulfi & & & $\checkmark$ & & $\checkmark$ & \\
\hline 16 & Teguh & & $\checkmark$ & & & & $\checkmark$ \\
\hline 17 & Fahry & & $\checkmark$ & & & & $\checkmark$ \\
\hline 18 & Niken & & & & $\checkmark$ & $\checkmark$ & \\
\hline 19 & Azka & & $\checkmark$ & & & & $\checkmark$ \\
\hline 20 & Shafa & & & $\checkmark$ & & $\checkmark$ & \\
\hline 21 & Kanza & & & $\checkmark$ & & $\checkmark$ & \\
\hline \multicolumn{2}{|c|}{ Jumlah } & 1 & 6 & 11 & 3 & 14 & 7 \\
\hline \multicolumn{2}{|c|}{ Prosentase } & $\begin{array}{c}4, \\
9 \\
\%\end{array}$ & $\begin{array}{l}28 \\
5 \\
\%\end{array}$ & $\begin{array}{l}52 \\
4 \\
\%\end{array}$ & $\begin{array}{l}14 \\
, 2 \\
\%\end{array}$ & $\begin{array}{c}66,7 \\
\%\end{array}$ & $\begin{array}{c}33,3 \\
\%\end{array}$ \\
\hline
\end{tabular}

Prosentase hasil perkembangan kemampuan dasar kognitif anak tersebut diperoleh dari:

1) Kelompok anak belum berkembang:

$\mathrm{P}=-\frac{\mathrm{x}}{\mathrm{N}} 100 \%$

$\mathrm{P}=2 \mathrm{2} \times 100 \%=4,9 \%$

2) Kelompok anak mulai berkembang:

$\mathrm{P}=\pi \times 100 \%$

$\mathrm{P}=\mathrm{x} 100 \%=28,5 \%$

3) Kelompok anak berkembang sesuai harapan:

$\mathrm{P}=\frac{\mathrm{X}}{\mathrm{x}} \times 100 \%$

$\mathrm{P}=\frac{\mathrm{Ud}}{\mathrm{Ud}} \times 100 \%=52,4 \%$

4) Kelompok anak berkembang sangat baik:

$\mathrm{P}=\mathbf{X}_{\mathrm{X}} \mathbf{1 0 0 \%}$

$\mathrm{P}=\frac{\mathrm{C}}{\mathrm{ha}} \times 100 \%=14,2 \%$

5) Prosentase ketuntasan anak:
$\mathrm{P}=\underline{\underline{n}} \times 100 \%$

$\mathrm{P}=\stackrel{\bar{N}}{\overline{=}} \times 100 \%=66,7 \%$

6) Prosentase ketidak tuntasan anak:

$$
\begin{aligned}
& \mathrm{P}=\frac{\dot{\bar{T}}}{\bar{T}} \times 100 \% \\
& \mathrm{P}=\frac{\overline{\mathrm{i}}}{\bar{T}} \times 100 \%=33,3 \%
\end{aligned}
$$

d. Refleksi

Berdasar hasil unjuk kerja pada siklus I menunjukkan bahwa peneliti/guru telah aktif dalam memberikan contoh bermain Permainan

Rainbowling, aktif dalam melakukan tanya jawab seputar hasil yang didapat setelah melempar bola dalam kegiatan Permainan Rainbowling, namun peneliti/guru belum menyampaikan tujuan pembelajaran, belum menjelaskan bahan yang digunakan untuk membuat Permainan Rainbowling, dan kurang dalam memotivasi anak dalam melaksanakan kegiatan bermain

Permainan

Rainbowling.

Sedangkan

perkembangan kemampuan dasar kognitif anak didik kelompok B-1 yang telah diupayakan melalui permainan Permainan Rainbowling dapat dilihat berdasarkan prosentase ketuntasan belajar pada siklus I, yaitu $33,3 \%$ prosentase ketidaktuntasan sedangkan $66,7 \%$ adalah prosentase ketuntasan. Dari hasil tersebut dapat disimpulkan bahwa kegiatan pada siklus I belum dapat meningkatkan kemampuan dasar kognitif anak didik, sehingga perlu perbaikan pada siklus II.

2. Pelaksanaan Tindakan pada Siklus II 
a. Perencanaan

Peneliti melakukan halhal sebagai berikut:

1) Mempersiapkan Rencana Program Pembelajaran Mingguan (RPPM)

2) Mempersiapkan Rencana Program Pembelajaran Harian (RPPH)

3) Mempersiapkan materi dengan Permainan Rainbowling

4) Mempersiapkan format penilaian kemampuan dasar kognitif

b. Pelaksanaan

Pada pelaksanaan siklus I, 21 anak didik kelompok B-1 TK Islam Al-Falah hadir.Pada tahap ini peneliti menerapkan kegiatan sesuai dengan persiapan yang telah direncanakan sebelumnya yaitu mengacu pada RPPM dan RPPH yang telah disusun. Secara garis besar kegiatan yang dilakukan dalam proses pembelajaran dalam siklus II ini adalah sebagai berikut:

1) Guru menyampaikan tujuan pembelajaran

2) Guru menjelaskan bahan yang digunakan untuk membuat Permainan Rainbowling

3) Guru aktif dalam memberikan contoh bermain Permainan Rainbowling

4) Guru aktif melakukan tanya jawab seputar hasil yang didapat setelah melempar bola dalam kegiatan Permainan Rainbowling

5) Guru memotivasi anak dalam melaksanakan kegiatan bermain Permainan Rainbowling

c. Observasi
Pada tahap observasi siklus II ini, peneliti melakukan observasi sesuai dengan format yang telah dibuat. Hal ini bertujuan untuk mengetahui danmemperoleh gambaran tentang perkembangan proses pembelajaran yang terjadi setelah pelaksanaan siklus I. Observasi dilakukan pada anak didik kelompok B1 dan pada peneliti/ guru.Adapun hasil observasi tersebut pada siklus II sebagai berikut:

Tabel 4.3

Lembar Hasil Observasi pada Guru dalam Kegiatan Mengembangkan Kemampuan

Dasar Kognitif Anak Didik melalui Permainan Rainbowling pada Siklus II

\begin{tabular}{|c|c|c|c|}
\hline No & Item observasi & $\mathrm{Ya}$ & Tidak \\
\hline 1 & $\begin{array}{l}\text { Guru menyampaikan } \\
\text { tujuan pembelajaran }\end{array}$ & $\checkmark$ & \\
\hline 2 & $\begin{array}{l}\text { Guru menjelaskan bahan } \\
\text { yang digunakan untuk } \\
\text { membuat Permainan } \\
\text { Rainbowling }\end{array}$ & $\checkmark$ & \\
\hline 3 & $\begin{array}{l}\text { Guru aktif dalam } \\
\text { memberikan contoh } \\
\text { bermain Permainan } \\
\text { Rainbowling }\end{array}$ & $\checkmark$ & \\
\hline 4 & $\begin{array}{l}\text { Guru aktif melakukan } \\
\text { tanya jawab seputar hasil } \\
\text { yang didapat setelah } \\
\text { melempar bola dalam } \\
\text { kegiatan Permainan } \\
\text { Rainbowling }\end{array}$ & $\checkmark$ & \\
\hline 5 & $\begin{array}{l}\text { Guru memotivasi anak } \\
\text { dalam melaksanakan } \\
\text { kegiatan bermain } \\
\text { Permainan Rainbowling }\end{array}$ & $\checkmark$ & \\
\hline
\end{tabular}

Tabel 4.4

Lembar Penilaian Perkembangan

Kemampuan

Dasar Kognitif Anak Didik pada Siklus II

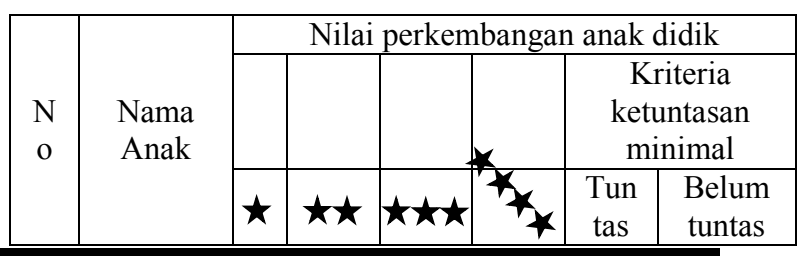




\begin{tabular}{|c|l|c|c|c|c|c|c|}
\hline 1 & Amel & & & & $\checkmark$ & $\checkmark$ & \\
\hline 2 & Aar & & & & $\checkmark$ & $\checkmark$ & \\
\hline 3 & Atta & & & $\checkmark$ & & $\checkmark$ & \\
\hline 4 & Dhea & & & $\checkmark$ & & $\checkmark$ & \\
\hline 5 & Delvin & & & & $\checkmark$ & $\checkmark$ & \\
\hline 6 & Dimas & & & $\checkmark$ & & $\checkmark$ & \\
\hline 7 & Andika & & $\checkmark$ & & & & $\checkmark$ \\
\hline 8 & Vano & & & $\checkmark$ & & $\checkmark$ & \\
\hline 9 & Satria & & & $\checkmark$ & & $\checkmark$ & \\
\hline 10 & Rafi & & $\checkmark$ & & & & $\checkmark$ \\
\hline 11 & Nara & & & $\checkmark$ & & $\checkmark$ & \\
\hline 12 & Salsa & & & & $\checkmark$ & $\checkmark$ & \\
\hline 13 & Bella & & & $\checkmark$ & & $\checkmark$ & \\
\hline 14 & Vino & $\checkmark$ & & & & & $\checkmark$ \\
\hline 15 & Zulfi & & & & $\checkmark$ & $\checkmark$ & \\
\hline 16 & Teguh & & & $\checkmark$ & & $\checkmark$ & \\
\hline 17 & Fahry & & & $\checkmark$ & & $\checkmark$ & \\
\hline 18 & Niken & & & $\checkmark$ & & $\checkmark$ & \\
\hline 19 & Azka & & & $\checkmark$ & & $\checkmark$ & \\
\hline 20 & Shafa & & & $\checkmark$ & & $\checkmark$ & \\
\hline 21 & Kanza & & & & $\checkmark$ & $\checkmark$ & \\
\hline \multicolumn{2}{|l|}{ Jumlah } & 1 & 2 & 12 & 6 & 18 & 3 \\
\hline Prosentase & 4 & 9,5 & 57,1 & 28,5 & 85,7 & $14,3 \%$ \\
& & $\%$ & $\%$ & \\
\hline
\end{tabular}

Prosentase hasil perkembangan kemampuan dasar kognitif anak tersebut diperoleh dari:

1) Kelompok anak belum berkembang:

$\mathrm{P}=\Perp \mathrm{x} 100 \%$

$\mathrm{P}=\frac{\mathrm{b}}{1} \times 100 \%=4,9 \%$

2) Kelompok anak mulai berkembang:

$\mathrm{P}=\pi \times 100 \%$

$\mathrm{P}=$ 工 $\times 100 \%=9,5 \%$

3) Kelompok anak berkembang sesuai harapan: $\mathrm{P}=\frac{\mathbf{x}}{\mathrm{x}} \times 100 \%$

$\mathrm{P}=\frac{\mathbf{v}}{\mathrm{va}} \times 100 \%=57,1 \%$

4) Kelompok anak berkembang sangat baik:

$\mathrm{P}=\underline{\mathrm{X}} \times 100 \%$

$\mathrm{P}=\frac{\mathrm{C}}{\mathrm{Da}} \times 100 \%=28,5 \%$

5) Prosentase ketuntasan anak:

$\mathrm{P}=-\mathrm{x} 100 \%$

$$
\mathrm{P}=\underline{\underline{\underline{A}}} \times 100 \%=85,7 \%
$$

6) Prosentase ketidak tuntasan anak:

$$
\begin{aligned}
& \mathrm{P}=\frac{\ddot{\sigma}}{\mathrm{m}} \times 100 \% \\
& \mathrm{P}=\frac{\dot{\mathrm{V}}}{\underline{a}} \times 100 \%=14,3 \%
\end{aligned}
$$

d. Refleksi

$\begin{array}{ccr}\text { Berdasar } & \text { hasil unjuk } \\ \text { kerja } & \text { pada } & \text { siklus }\end{array}$ menunjukkan bahwa peneliti/ guru telah aktif dalam memberikan contoh bermain Rainbowling Game, aktif dalam melakukan tanya jawab seputar hasil yang didapat setelah melempar bola dalam kegiatan Permainan Rainbowling, peneliti/guru menyampaikan tujuan pembelajaran, menjelaskan bahan yang digunakan untuk membuat Permainan Rainbowling, dan memotivasi anak dalam melaksanakan kegiatan bermain Permainan Rainbowling.

Sedangkan

perkembangan kemampuan dasar kognitif anak didik kelompok B1 yang telah diupayakan melalui permainan Permainan Rainbowling dapat dilihat berdasarkan prosentase ketuntasan belajar pada siklus II.Anak mengalami perkembangan daripada siklus I.

Berdasarkan hasil pelaksanaan tindakan yang dilakukan, kemampuan dasar kognitif anak didik yang diupayakan melalui permainan Permainan Rainbowling pada anak didik kelompok B-1 TK Islam Al-Falah Kecamatan Pesantren Kota Kediri mengalami peningkatan yang lebih baik dari sebelumnya. Peningkatan kemampuan dasar kognitif anak didik dapat dilihat dari tabel perbandingan perolehan hasil belajar anak serta tabel hasil ketuntasan belajar anak didik sebagai berikut: 
Tabel 4.5

Hasil Penilaian Kemampuan Dasar Kognitif Anak Didik Kelompok B-1 TK Islam Al-Falah Pesantren Sebelum dan Sesudah Tindakan

\begin{tabular}{|c|c|c|c|c|}
\hline No & $\begin{array}{c}\text { Hasil } \\
\text { Penilaian }\end{array}$ & $\begin{array}{c}\text { Pra } \\
\text { Tindakan }\end{array}$ & $\begin{array}{c}\text { Tindakan } \\
\text { Siklus I }\end{array}$ & $\begin{array}{l}\text { Tindakan } \\
\text { Siklus II }\end{array}$ \\
\hline 1 & $\star$ & $4,9 \%$ & $4,9 \%$ & $4,9 \%$ \\
\hline 2 & $\star \star$ & $28,5 \%$ & $28,5 \%$ & $9,5 \%$ \\
\hline 3 & 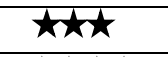 & $52,4 \%$ & $52,4 \%$ & $57,1 \%$ \\
\hline 4 & 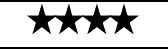 & $14,2 \%$ & $14,2 \%$ & $28,5 \%$ \\
\hline \multicolumn{2}{|c|}{ Jumlah } & $100 \%$ & $100 \%$ & $100 \%$ \\
\hline
\end{tabular}

Tabel 4.6

Hasil Ketuntasan Kemampuan Dasar Kognitif Anak Didik Kelompok B-1

TK Islam Al-Falah Pesantren Sebelum dan Sesudah Tindakan

\begin{tabular}{|c|c|c|c|}
\hline \multirow{2}{*}{ Siklus } & \multicolumn{2}{|c|}{ Jumlah Anak Didik } & Prosentase \\
\cline { 2 - 3 } & $\begin{array}{l}\text { Belum } \\
\text { Tuntas }\end{array}$ & Tuntas & Ketuntasan \\
\hline I & 7 & 14 & $66,7 \%$ \\
\hline II & 3 & 18 & $85,7 \%$ \\
\hline & Berdasarkan data di atas, \\
ketuntasan kemampuan dasar \\
kognitif anak didik mengalami \\
peningkatan. Hal tersebut nampak \\
dari prosentase ketuntasan \\
kemampuan dasar kognitif anak \\
didik pada pratindakan dan pada \\
siklus I yang hanya mencapai 66,7\%. \\
Kemudian kemampuan dasar \\
kognitif anak didik mengalami \\
peningkatan pada siklus II yaitu \\
85,7\%.
\end{tabular}

2. Pengambilan Simpulan

Dengan demikian dapat disimpulkan bahwa pembelajaran melalui Permainan Rainbowling dapat mengembangkan kemampuan dasar kognitif anak didik kelompok B-1 TK Islam Al-Falah Kecamatan Pesantren Kota Kediri Tahun Ajaran 2015-2016, sehingga hipotesis tindakan dalam penelitian ini diterima.

\section{SIMPULAN DAN SARAN}

Simpulan

Berdasarkan hasil penelitian dan pembahasan yang dilakukan dapat disimpulkan bahwa melalui Permainan Rainbowling dapat mengembangkan kemampuan dasar kognitif anak didik kelompok B-1 TK Islam Al-Falah Kecamatan Pesantren Kota Kediri Tahun Ajaran 2015/2016.

Selain itu minat anak untuk memahami konsep berhitung semakin meningkat setelah dilakukan dengan permainan Permainan Rainbowling.

\section{Saran}

1. Bagi Guru

Hasil prestasi belajar anak didik yang telah dicapai dalam penelitian ini hendaknya tetap diperhatikan bahkan ditingkatkan.Peningkatan hasil belajar sebaiknya tidak hanya pada kemampuan kognitif tetapi juga semua aspek perkembangan dengan media dan metode pembelajaran yang lebih menarik.

2. Bagi Anak Didik

Diharapkan dengan media ataupun metode pembelajaran yang menarik dan inovatif anak lebih aktif, kreatif, nyaman, aman, dan mudah dalam menerima materi pembelajaran sehingga kemampuan yang diharapkan dapat tercapai dengan optimal.

\section{DAFTAR PUSTAKA}
Moeslichatoen.2005. Metode Pengajaran
Taman Kanak-kanak. Jakarta:
Departemen Pendidikan dan
Kebudayaan Direktoral Jenderal
Pendidikan Tinggi Proyek
Pendidikan Tenaga Akademik
Mulyasa, E. 2006.Menjadi Guru
Profesional. Bandung: PT. Remaja
Rosda Karya 
Patmonodewo, Soemiarti Utami. 1996. Cerdas dan Cemerlang. Jakarta: PT. Gramedia Pustaka Utama

Sulastri.2012. Mengembangkan Fisik Motorik Kasar Anak melalui Gerak Tari pada Siswa Kelompok B di TK Dharma Wanita Pakunden I Kota
Kediri.Skripsi tidak diterbitkan. Kediri: Fakultas Keguruan dan Ilmu Pendidikan UNP Kediri

Wikipedia. 2015. Bowling, (online), (http://id.m.wikipedia.org/wiki/Boli ng, diakses tanggal 19 April 2016 